\title{
World Journal of Effect of nalbuphine on rocuronium injection pain
} Wenfang Huang, Jinjin Huang, Dongpi Wang, Yaoqin Hu, Jiangmei Wang,
Hongfei Lin

To cite: Huang W, Huang J, Wang $\mathrm{D}$, et al. Effect of nalbuphine on rocuronium injection pain. World JnI Ped Surgery 2021;4:e000249. doi:10.1136/ wjps-2020-000249

Received 3 December 2020 Revised 12 April 2021 Accepted 13 April 2021

\section{Check for updates}

(c) Author(s) (or their employer(s)) 2021. Re-use permitted under CC BY-NC. No commercial re-use. See rights and permissions. Published by BMJ.

Department of Anesthesiology, Zhejiang University School of Medicine Children's Hospital, Hangzhou, China

Correspondence to Jinjin Huang; 6196008@zju. edu.cn

\section{ABSTRACT}

Objective Rocuronium-associated intravenous injection pain occurs frequently in children during induction of anesthesia. The aim of this study was to systematically evaluate the benefits of nalbuphine in patients with rocuronium-associated injection pain.

Methods Ninety children undergoing tonsillectomy and adenoidectomy in our hospital between October 2019 and September 2020 were randomly divided into the following groups, with 30 patients per group: control group (group C), lidocaine group (group L), and nalbuphine group (group N). Routine $0.1 \mathrm{mg} / \mathrm{kg}$ midazolam and $2 \mathrm{mg} / \mathrm{kg}$ propofol were injected intravenously. After sedation, children in group C, group $\mathrm{L}$, and group $\mathrm{N}$ were administered an intravenous injection of saline, lidocaine $(10 \mathrm{mg} / \mathrm{mL})$, or nalbuphine hydrochloride (2 mg/mL), respectively, at a dosage of 0.1 $\mathrm{mL} / \mathrm{kg}$. Intravenous injection of rocuronium stock solution $(0.6 \mathrm{mg} / \mathrm{kg})$ was administered 2 minutes later. Pain was evaluated using Ambeshs 4-pointscale. The incidence of rocuronium injection pain was compared among the three groups, and postoperative adverse reactions, such as drowsiness, bradycardia, hypotension, and respiratory depression, were evaluated.

Results The incidence of injection pain among children in group $\mathrm{N}$ was significantly lower than that in group $\mathrm{C}$ and group $L(p<0.05)$. The incidence of drowsiness in group $\mathrm{N}$ was significantly higher than that in the other groups $(p<0.05)$. The incidences of hypotension, bradycardia, and respiratory depression were not significantly different among the three groups ( $p>0.05$ ).

Conclusions Intravenous nalbuphine during induction of anesthesia effectively prevented rocuronium-associated injection pain in children. Drowsiness is a complication.

\section{INTRODUCTION}

Rocuronium is a non-depolarizing muscle relaxant with an intermediate effect. Compared with other non-depolarizing muscle relaxants such as vecuronium bromide and atracurium, rocuronium has a rapid onset effect. ${ }^{1}$ Due to this property, rocuronium is used for tracheal intubation during induction of routine anesthesia and maintenance of intraoperative skeletal muscle relaxation. Local pain caused by rocuronium injection is a challenge for anesthesiologists because the incidence of such pain occurs in 50\%-80\% of adults and in $83 \%-94 \%$ of children. ${ }^{2-4}$ Rocuronium-associated injection pain occurs
Key messages

What is already known about this subject?

$>$ Rocuronium-associated intravenous injection pain occurs frequently in children during induction of anesthesia.

- Pain can immediately cause withdrawal movements which can lead to increased incidence of pulmonary aspiration in unconscious patients, detachment or displacement of venous catheters, or other emergencies.

- Lidocaine is considered one of the most effective drugs for preventing rocuronium injection pain; however, the use of lidocaine alone cannot completely prevent injection pain

- Nalbuphine is mainly used to relieve severe pain and pediatric perioperative pain.

What are the new findings?

- This study showed that injecting nalbuphine before rocuronium effectively reduced the incidence of rocuronium injection pain.

- Compared with lidocaine, nalbuphine was more effective in reducing rocuronium-associated injection pain.

- Due to its sedative effect, nalbuphine might be more suitable for children than lidocaine.

How might it impact on clinical practice in the foreseeable future?

- Nalbuphine might be a reasonable drug to reduce rocuronium injection pain.

in conscious patients. Even after induction of anesthesia, it can produce burning pain. The pain can immediately cause withdrawal movements of the arm and hand and may soon extend to the whole body. ${ }^{5}$ This type of body movement reactions can lead to increased incidence of pulmonary aspiration in unconscious patients, detachment or displacement of venous catheters, or other emergencies. Therefore, reducing pain caused by rocuronium injection has important consequences in clinical application.

Lidocaine is considered one of the most effective drugs for preventing rocuronium injection pain. ${ }^{6}$ In addition to drug prophylaxis, studies have shown that the dilution of 
rocuronium to a lower concentration can also reduce the incidence of injection pain. ${ }^{5}$ However, the use of lidocaine alone or of low concentrations of rocuronium alone cannot completely prevent injection pain. Many randomized controlled trials in adults have shown that a variety of opioids, such as fentanyl and sufentanil, can effectively reduce the incidence and severity of pain or muscular fasciculations caused by injection of rocuronium. ${ }^{7-9}$ However, the use of fentanyl and sufentanil in children is associated with risk of chest wall stiffness and reductions in oxygen saturation.

Nalbuphine is a synthetic opioid agonist-antagonist and its structure is similar to those of naloxone and hydromorphone. ${ }^{10}$ Nalbuphine can produce mild to moderate analgesia through $\mu$ opioid receptor and kappa opioid receptor activation. ${ }^{11}$ Numerous studies have reported its advantages in pain management. ${ }^{12}$

The aim of our study was to systematically evaluate the benefits of nalbuphine in patients with rocuroniumassociated injection pain.

\section{METHODS}

\section{General information}

The parents of patients participating in this study provided written informed consent.

The study comprised a total of 90 patients, aged 4-8 years, who were in American Society of Anesthesiologist (ASA) I risk group, and had undergone tonsillectomy and adenoidectomy at the Children's Hospital, Zhejiang University School of Medicine between October 2019 and September 2020. Patients who had a recent history of hepatic or renal insufficiency, severe allergic or hypersensitivity reaction to the study drugs, cardiovascular or neurological disease, and those taking opioids were excluded.

Using a computer-based random number method, children were randomly divided into three groups, with 30 patients each group: control group (group C), lidocaine group (group L), and nalbuphine group (group N).

\section{Anesthesia methods}

Children underwent intravenous catheterization with a 24 G retention needle before entering the operating room. Once inside the operating room, each patient underwent electrocardiogram (ECG), non-invasive blood pressure (NIBP) measurement, and percutaneous oxygen saturation $\left(\mathrm{SpO}_{2}\right)$ monitoring, and received oxygen through a mask. The patients in all three groups were treated with
$0.1 \mathrm{mg} / \mathrm{kg}$ midazolam and $2 \mathrm{mg} / \mathrm{kg}$ propofol. After sedation, the children received intravenous administration of saline, nalbuphine $(10 \mathrm{mg} / \mathrm{mL})$, or lidocaine $(2 \mathrm{mg} /$ $\mathrm{mL}$ ) at a dose of $0.1 \mathrm{~mL} / \mathrm{kg}$. All three groups were administered $0.6 \mathrm{mg} / \mathrm{kg}$ rocuronium 2 minutes later, and $2 \mu \mathrm{g} /$ $\mathrm{kg}$ remifentanil was given after muscle relaxation. Intraoperative remifentanil $(0.5 \mu \mathrm{g} / \mathrm{kg} / \mathrm{min})$ and propofol $(100 \mu \mathrm{g} / \mathrm{kg} / \mathrm{min})$ administration was maintained until the surgery was terminated.

\section{Observation indicators}

All data were recorded by the same anesthesiologist, who recorded (1) NIBP, heart rate (HR), and $\mathrm{SpO}_{2}$ after entering the room (T1) and at the time of rocuronium injection (T2); and (2) pain scores, which were evaluated using Ambesh's 4-point scale during injection of rocuronium. Pain was graded based on the following scale: 0 , no pain response; 1 , mild pain (pain, but no body reaction); 2, moderate pain (pain with obvious limb retraction or movement); and 3, severe pain (painful expression, accompanied by contraction, frowning, and tearing).

Drowsiness means that the patient can be awakened and can answer questions correctly, but without the stimulation, the patient falls asleep soon. Bradycardia was defined as reduction in HR of $<60$ beats per minute (BPM); $0.1 \mathrm{mg} / \mathrm{kg}$ atropine was given when HR decreased to $<60$ BPM. ${ }^{13}$ Hypotension was defined as systolic blood pressure (SBP) $<80 \mathrm{mmHg}$ or SBP decline of $>30 \%$ compared with baseline. Respiratory depression was considered if $\mathrm{SpO}_{2}$ was $<90 \%$, respiratory rate was $<6$ breaths per minute, or if airway obstruction with cessation of gas exchange was observed at any time. Jaw thrust and chin lift maneuvers were performed in the event of respiratory depression.

\section{Statistical analysis}

The collected data were analyzed using SPSS V.22.0 statistical software. Measurement data are expressed as mean \pmstandard deviation (SD). We used analyses of variance to compare data among the three groups. $\chi^{2}$ test was used to analyze the incidence of pain induced by rocuronium, ASA class, and gender. $\mathrm{P}<0.05$ was defined as statistically significant.

\begin{tabular}{lllll}
\hline \multicolumn{7}{l}{ Table 1} & Demographic data of patients and propofol dose in three groups \\
\hline & Group C ( $\mathbf{n}=\mathbf{3 0})$ & Group L $(\mathbf{n}=\mathbf{3 0})$ & Group N ( $\mathbf{n}=\mathbf{3 0})$ & P value \\
\hline Gender (female:male), $n$ & $9: 21$ & $10: 20$ & $15: 15$ & 0.231 \\
Age (mon), mean \pm SD & $6.05 \pm 2.23$ & $5.40 \pm 1.33$ & $5.31 \pm 1.19$ & 0.17 \\
Weight (kg), mean \pm SD & $25.55 \pm 6.16$ & $22.31 \pm 4.56$ & $24.63 \pm 5.17$ & 0.342 \\
\hline
\end{tabular}

Group C, control group; group L, lidocaine group; group N, nalbuphine group; SD, standard deviation. 


\begin{tabular}{|c|c|c|c|}
\hline Vital signs & Group $(n=30)$ & T1 & T2 \\
\hline \multirow{3}{*}{$\begin{array}{l}\text { HR (BPM), } \\
\text { mean } \pm S D\end{array}$} & Group C & $111 \pm 16$ & $109 \pm 20$ \\
\hline & Group L & $104 \pm 6$ & $112 \pm 7$ \\
\hline & Group N & $103 \pm 7$ & $102 \pm 7^{*}$ \\
\hline \multirow{3}{*}{$\begin{array}{l}\text { MAP }(\mathrm{mmHg}) \\
\text { mean } \pm S D\end{array}$} & Group C & $73 \pm 5$ & $72 \pm 4^{\star \star}$ \\
\hline & Group L & $73 \pm 4$ & $72 \pm 4^{\star \star \star}$ \\
\hline & Group N & $72 \pm 4$ & $69 \pm 4$ \\
\hline \multirow[t]{3}{*}{$\mathrm{SpO}_{2}(\%)$} & Group C & 100 & 100 \\
\hline & Group L & 100 & 100 \\
\hline & Group N & 100 & 100 \\
\hline
\end{tabular}

${ }^{*} \mathrm{P}=0.001$ compared with $\mathrm{T} 1$ in the same group, ${ }^{*} \mathrm{P}=0.003$ compared with $\mathrm{T} 1$ in the same group, and ${ }^{* \star *} \mathrm{P}=0.00$ compared with $\mathrm{T} 1$ in the same group.

BPM, beats per minute; group C, control group; group L, lidocaine group; group N, nalbuphine group; HR, heart rate; MAP, mean arterial pressure; $\mathrm{SpO}_{2}$, percutaneous oxygen saturation.

\section{RESULTS}

\section{Demographic data}

There were no significant differences in age, sex, weight, and ASA classification among the three groups $(p>0.05$; table 1).

\section{Vital signs}

As shown in table 2, the values of HR, mean arterial pressure (MAP), and $\mathrm{SpO}_{2}$ at $\mathrm{T} 1$ were comparable among the groups $(\mathrm{p}>0.05)$. In group N, HR and MAP decreased significantly after anesthetic induction at T2. MAP also decreased significantly in group L.

\section{Comparison of injection pain among the groups}

The incidence of injection pain (Ambesh score $\geq 1$ ) was $96.7 \%$ in group C, $76.7 \%$ in group L, and $26.7 \%$ in group N. There was no significant difference between group $\mathrm{C}$ and group L $(\mathrm{p}>0.05)$. The incidence of injection pain in group $\mathrm{N}$ was significantly different $(p<0.05)$ from that in the other two groups (figure 1 and table 3 ).

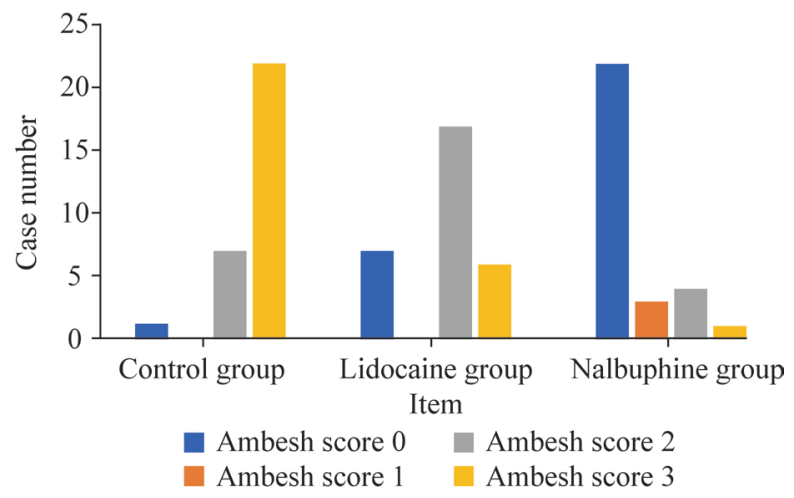

Figure 1 Incidence of Ambesh score 0 in the nalbuphine group was significantly higher than that in the control group and lidocaine group $(p=0.001)$.

\begin{tabular}{|c|c|c|c|}
\hline Item & $\begin{array}{l}\text { Group C } \\
(n=30)\end{array}$ & $\begin{array}{l}\text { Group L } \\
(n=30)\end{array}$ & $\begin{array}{l}\text { Group N } \\
(n=30)\end{array}$ \\
\hline Ambesh score 0 & $1(3.3)$ & 7 (23.3) & $22(73.3)$ \\
\hline Ambesh score 1 & $0(0)$ & $0(0)$ & $3(10)$ \\
\hline Ambesh score 2 & 7 (23.3) & $17(56.7)$ & $4(13.3)$ \\
\hline Ambesh score 3 & 22 (73.3) & $6(20)$ & $1(3.3)$ \\
\hline $\begin{array}{l}\text { Incidence of } \\
\text { injection pain }\end{array}$ & $29(96.7)$ & $23(76.7)$ & $8^{*}(26.7)$ \\
\hline
\end{tabular}

Data are shown as $\mathrm{n}(\%)$.

${ }^{*}$ Comparison among the nalbuphine group and the control and lidocaine groups $(p=0.001)$.

Group C, control group; group L, lidocaine group; group N, nalbuphine group.

\section{Comparison of other adverse reactions among the groups}

Comparison of children in the three groups indicated that the incidence of drowsiness in group N (30\%) was significantly higher than that in the other two groups $(\mathrm{p}<0.05)$, whereas bradycardia, hypotension, and respiratory depression were not significantly different (figure 2 and table 4 ).

\section{DISCUSSION}

This study showed that injecting nalbuphine before rocuronium could effectively reduce the incidence of rocuronium injection pain. The mechanism of rocuroniumrelated injection pain remains unknown. It was reported that polymodal nociceptors invested peripheral veins, after being stimulated by unphysiological osmolarity or $\mathrm{pH}$ of the drug solution, endogenous pain mediators such as prostaglandins were released. ${ }^{14}$ The $\mathrm{pH}$ of rocuronium is 4.0; neutralized dilution could increase the $\mathrm{pH}$ and reduce injection pain. ${ }^{1516}$ The dolorific effect of rocuronium might be due to the calcitonin prostaglandin E2 and gene-related peptide, which leads to direct activation of $\mathrm{C}$ receptor nerve endings. ${ }^{17}$

Nalbuphine is an opioid receptor agonist (antagonist analgesic) which mainly acts on the kappa receptor in the

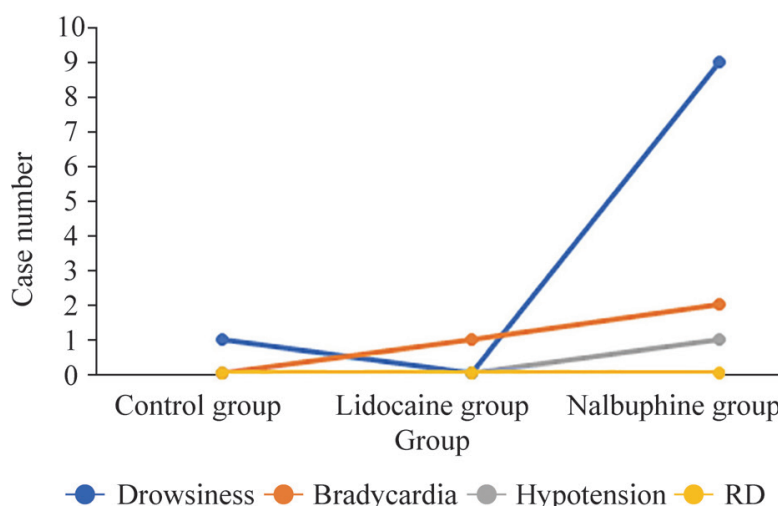

Figure 2 Compared with the control group and the lidocaine group, the incidence of drowsiness in the nalbuphine group increased significantly $(p=0.000)$. RD, respiratory depression. 


\begin{tabular}{llll}
\hline Table 4 & \multicolumn{3}{c}{ Comparison of adverse reactions } \\
\hline Adverse reactions & $\begin{array}{l}\text { Group C } \\
(\mathbf{n}=\mathbf{3 0})\end{array}$ & $\begin{array}{l}\text { Group L } \\
(\mathbf{n}=\mathbf{3 0})\end{array}$ & $\begin{array}{l}\text { Group N } \\
(\mathbf{n}=30)\end{array}$ \\
\hline Drowsiness & $1(3.3)$ & $0(0)$ & $9^{*}(30)$ \\
\hline Bradycardia & $0(0)$ & $1(3.3)$ & $2(6.7)$ \\
Hypotension & $0(0)$ & $0(0)$ & $1(3.3)$ \\
Respiratory depression & $0(0)$ & $0(0)$ & $0(0)$
\end{tabular}

Data are shown as $\mathrm{n}(\%)$.

*Postoperative drowsiness in the nalbuphine group compared with those in the control and lidocaine groups $(p=0.000)$.

Group C, control group; group L, lidocaine group; group N, nalbuphine group.

spinal cord, and can relieve severe pain (such as burns, biliary colic, cancer, or surgery pain) by activating the kappa receptor at the spinal cord level and the kappa 3 receptor at the upper spinal cord. ${ }^{18}$ Nalbuphine is also used as an analgesic for angina pectoris, myocardial infarction, postoperative pain, etc. Compared with dezocine and morphine, nalbuphine can relieve adverse reactions such as respiratory depression, nausea, itching, and vomiting, without increasing blood pressure. It also works quickly and lasts long and therefore can be used for pediatric postoperative analgesia. ${ }^{19}$

According to the Chinese Society of Anesthesiology, in principle, systemic opioids should be less used for patients who need surgery ${ }^{20}$ because they often cause excessive sedation and respiratory inhibition, even nausea, vomiting, pruritus, and urinary retention. ${ }^{21} \mathrm{~A}$ meta-analysis of randomized controlled trials showed that compared with morphine, nalbuphine had similar analgesic effects ${ }^{22}$ but lack opioid-related adverse effects, such as itching. ${ }^{23}$ Nalbuphine provided good analgesia of adequate duration and proved to be an acceptable alternative to lidocaine. ${ }^{24}$ The pros and cons of the results indicate that nalbuphine might be more suitable for pretreatment due to reduced pain during intravenous injection.

The results showed that MAP and HR decreased significantly after induction of anesthesia at T2 in group $\mathrm{N}$. The incidence of postoperative drowsiness was higher in group $\mathrm{N}$ than that in other groups, whereas the incidence of other adverse reactions was similar. Drowsiness is one of the common complications of analgesics. The incidence of drowsiness in adults after nalbuphine administration was $32 \%$ according to a study by Kubica-Cielińska and Zielińska. ${ }^{10}$ In one study, a newborn was mistakenly given a dose 10 times higher than the dose required for nalbuphine, which resulted in prolonged sedation without respiratory failure. ${ }^{25}$ Some studies had shown that nalbuphine injection before anesthesia could reduce stress reaction due to decreased fluctuations in HR and blood pressure during intubation, which might be due to pain relief. ${ }^{23}$ In this case, the occurrence of drowsiness may also have been due to the analgesic effect of nalbuphine. Intravenous lidocaine blocks $\mathrm{Na}^{+}$channels in the heart, which inhibites sympathetic transmission and depresses the hemodynamic response,${ }^{26}$ and so the MAP decreases significantly in group L.

In conclusion, this study suggested that nalbuphine might be a reasonable drug to reduce rocuronium injection pain in pediatrics. Drowsiness is a complication.

Contributors WFH and YH contributed to writing-original draft. DW and $\mathrm{HL}$ contributed to data curation. JW contributed to formal analysis. JH contributed to writing-review and editing.

Funding The authors have not declared a specific grant for this research from any funding agency in the public, commercial or not-for-profit sectors.

Competing interests None declared.

Patient consent for publication Not required.

Ethics approval This study was approved by the Ethics Board of the Children's Hospital, Zhejiang University School of Medicine on September 30, 2019 (approval number: 2019-IRB-093).

Provenance and peer review Not commissioned; externally peer reviewed.

\section{Data availability statement Not applicable.}

Open access This is an open access article distributed in accordance with the Creative Commons Attribution Non Commercial (CC BY-NC 4.0) license, which permits others to distribute, remix, adapt, build upon this work non-commercially, and license their derivative works on different terms, provided the original work is properly cited, appropriate credit is given, any changes made indicated, and the use is non-commercial. See: http://creativecommons.org/licenses/by-nc/4.0/.

\section{REFERENCES}

1 Magorian T, Flannery KB, Miller RD. Comparison of rocuronium, succinylcholine, and vecuronium for rapid-sequence induction of anesthesia in adult patients. Anesthesiology 1993;79:913-8.

$2 \mathrm{Kim}$ JY, Kwak HJ, Kim JY, et al. Prevention of rocuronium-induced withdrawal movement in children: a comparison of remifentanil with alfentanil. Paediatr Anaesth 2008;18:245-50.

3 Steegers MA, Robertson EN. Pain on injection of rocuronium bromide. Anesth Analg 1996;83:203.

4 Borgeat A, Kwiatkowski D, Ruetsch YA. Spontaneous movements associated with rocuronium injection: the effects of prior administration of fentanyl. $J$ Clin Anesth 1997;9:650-2.

5 Wang J, Cui Y, Liu B, et al. The efficacy of antipyretic analgesics administration intravenously for preventing Rocuronium-Associated Pain/Withdrawal response: a systematic review and meta-analysis. BMC Anesthesiol 2020;20:89.

6 Ahmad N, Choy CY, Aris EA, et al. Preventing the withdrawal response associated with rocuronium injection: a comparison of fentanyl with lidocaine. Anesth Analg 2005;100:987-90.

7 Şimșek Ülkü H, Güneș Y, llgınel M, et al. [Effect of rocuronium administration rate and remifentanil on prevention of rocuronium injection pain in pediatric cases]. Agri 2017;29:162-6.

8 Park S. Prevention of rocuronium injection pain. Korean $J$ Anesthesiol 2014;67:371-2

$9 \mathrm{He} \mathrm{L}$, Ding Y, Chen H, et al. Butorphanol pre-treatment prevents myoclonus induced by etomidate: a randomised, double-blind, controlled clinical trial. Swiss Med Wkly 2014;144:w14042.

10 Kubica-Cielińska A, Zielińska M. The use of nalbuphine in paediatric anaesthesia. Anaesthesiol Intensive Ther 2015;47:252-6.

11 Zacny JP, Conley K, Marks S. Comparing the subjective, psychomotor and physiological effects of intravenous nalbuphine and morphine in healthy volunteers. J Pharmacol Exp Ther 1997;280:1159-69.

12 Shin D, Kim S, Kim CS, et al. Postoperative pain management using intravenous patient-controlled analgesia for pediatric patients. $J$ Craniofac Surg 2001;12:129-33.

13 Deng C, Wang X, Zhu Q, et al. Comparison of nalbuphine and sufentanil for colonoscopy: a randomized controlled trial. PLoS One 2017;12:e0188901

14 Arndt JO, Klement W. Pain evoked by polymodal stimulation of hand veins in humans. J Physiol 1991;440:467-78.

15 Shin YH, Kim CS, Lee JH, et al. Dilution and slow injection reduces the incidence of rocuronium-induced withdrawal movements in children. Korean J Anesthesiol 2011;61:465-9. 
16 Han DW, Koo BN, Choi SH, et al. Neutralized rocuronium ( $\mathrm{pH} 7.4)$ before administration prevents injection pain in awake patients: a randomized prospective trial. J Clin Anesth 2007;19:418-23.

17 Blunk JA, Seifert F, Schmelz M, et al. Injection pain of rocuronium and vecuronium is evoked by direct activation of nociceptive nerve endings. Eur J Anaesthesiol 2003;20:245-53.

18 Imam MZ, Kuo A, Ghassabian S, et al. Intracerebroventricular administration of CYX-6, a potent $\mu$-opioid receptor agonist, a $\delta$ and $\kappa$-opioid receptor antagonist and a biased ligand at mu, delta \& kappa-opioid receptors, evokes antinociception with minimal constipation and respiratory depression in rats in contrast to morphine. Eur J Pharmacol 2020;871:172918.

19 Dong Y, Liang Z, Xu Z, et al. Effects of dezocine, morphine and nalbuphine on electropain threshold, temperature pain threshold and cardiac function in rats with myocardial ischemia. Ann Palliat Med 2020;9:1556-63.

20 Guan YJ, Wei L, Liao Q, et al. Pain management after ambulatory surgery: a prospective, multicenter, randomized, double-blinded parallel controlled trial comparing nalbuphine and tramadol. BMC Anesthesiol 2020;20:204
21 Jitpakdee T, Mandee S. Strategies for preventing side effects of systemic opioid in postoperative pediatric patients. Paediatr Anaesth 2014;:24:561-8.

22 Zeng Z, Lu J, Shu C, et al. A comparision of nalbuphine with morphine for analgesic effects and safety : meta-analysis of randomized controlled trials. Sci Rep 2015;5:10927.

23 Chawda PM, Pareek MK, Mehta KD. Effect of nalbuphine on haemodynamic response to orotracheal intubation. J Anaesthesiol Clin Pharmacol 2010;26:458-60.

24 Prabhakar H, Singh GP, Ali Z, et al. Pharmacological and nonpharmacological interventions for reducing rocuronium bromide induced pain on injection in children and adults. Cochrane Database Syst Rev 2016;2:CD009346.

25 Schultz-Machata AM, Becke K, Weiss M. [Nalbuphine in pediatric anesthesia]. Anaesthesist 2014;63:135-43.

26 Zou Y, Kong G, Wei L, et al. The effect of intravenous lidocaine on hemodynamic response to endotracheal intubation during sufentanil-based induction of anaesthesia. Anaesthesiol Intensive Ther 2020;52:287-91. 